\title{
Sędzia w procesie o stwierdzenie nieważności małżeństwa
}

Kościół katolicki jest społecznością doskonałą, która ma z ustanowienia Bożego władzę rządzenia. Jej częścią składową jest władza sądownicza. Wypływa z niej uprawnienie organu władzy kościelnej do wymierzania sprawiedliwości. Jednym $\mathrm{z}$ najczęstszych procesów są sprawy dotyczące stwierdzenia nieważności małżeństwa. Sprawy te należą do dynamicznych z powodu różnorodności instytucji w nim występujących. Kolejność poszczególnych procedur procesu stanowi logiczną całość. W tym procesie istotną rolę do spełnienia ma osoba pełniąca urząd kościelny, jakim jest sędzia. Zadania sędziego wiążą się z pełnieniem tego urzędu, polegającym na sprawiedliwym stosowaniu prawa w Kościele.

\section{Obowiązki sędziego kościelnego}

Stwierdzenie nieważności małżeństwa uwarunkowane jest podaniem i udowodnieniem istnienia przyczyny, która sprawia, że zawarte małżeństwo od samego początku było nieważne. Przyczyny nieważności zawarcia małżeństwa mogą pochodzić z trzech źródeł, którymi są: przeszkody małżeńskie, niezdolność do wyrażenia zgody małżeńskiej i brak przepisanej przez prawo kanoniczne formy zawarcia małżeństwa. Najwięcej trudności w orzekaniu w sprawach małżeńskich sprawia dziedzina małżeńskiej zgody ${ }^{1}$. Dlatego przed sędzią kościelnym stoi trudne i odpowiedzialne zadanie uzyskania prawdy obiektywnej w rozpatrywanej sprawie.

1 Por. P. M. Gajda, Prawo małżeńskie Kościoła katolickiego, Tarnów 2005, s. 302-305. 
Tożsamość sędziego kościelnego wyznaczają normy prawa określające osobę, jej cechy i zadania oraz normy prawa dotyczące kościelnej władzy sądowniczej. Tę określoną prawem tożsamość sędzia ma obowiązek zachować w swoim postępowaniu. Sędzia kościelny wykonuje swój urząd w oparciu o autorytet publiczny, jakim cieszy się we wspólnocie Kościoła katolickiego. Nie tworzy on prawa kanonicznego, lecz aplikuje aktualne przepisy prawne do konkretnej, rozpatrywanej przez siebie sprawy sądowej. Sędzia, rozważając i analizując przypadek, musi stosować normy prawa, wydobywając z konkretnego przypadku te elementy, które mają istotne znaczenie. Istotne staje się osiągnięcie przed wyrokowaniem wewnętrznej pewności moralnej.

Przepisana przez Kodeks prawa kanonicznego procedura w sprawach małżeńskich przewiduje prawo każdego małżonka, nawet przy sprzeciwie współmałżonka, do wniesienia do trybunału kościelnego sprawy o stwierdzenie nieważności małżeństwa. Może to również uczynić rzecznik sprawiedliwości ${ }^{3}$, ale pod warunkiem, że zaistnieje nieważność małżeństwa, która została już rozgłoszona, a uważnienie małżeństwa nie jest możliwe lub nie jest nawet wskazane $e^{4}$. Poprzez skargę powodową strona usiłuje rozpocząć proces i dlatego przedstawia sędziemu ze swojej strony punkt widzenia, przyczyny i powody, na podstawie których uważa, że zostało naruszone jej prawo5. Sąd nie może rozpatrywać żadnej sprawy, jeśli ten, kto ma prawo zaskarżyć małżeństwo o nieważność, nie przedstawi prośby zgodnie z przepisami prawa kanonicznego ${ }^{6}$. Sędzia jest wyposażony we władzę sędziowską, by mógł działać wtedy, gdy zostanie mu przedłożona skarga powodowa ${ }^{7}$.

2 R. Sobański, Uwagi o tożsamości sędziego kościelnego, „Prawo Kanoniczne” 45 (2002) nr 3-4, s. 5 .

3 Codex Iuris canonici [dalej: cIc], c. 1674, por. J. Gręźlikowski, Co po rozwodzie? Duszpasterze i wierni świeccy wobec małżeństw niesakramentalnych i kanonicznego procesu o stwierdzenie nieważności małżeństwa, Częstochowa 2005, s. 241.

4 Por. G. Erlebach, Tytuł I. Procesy małżeńskie, [w:] Komentarz do Kodeksu Prawa Kanonicznego. T. 5. Ks. 7, Procesy, red. J. Krukowski, Poznań 2007, s. 337.

5 J. Gręźlikowski, Co po rozwodzie?..., dz. cyt., s. 241.

6 Por. W. Góralski, Małżeństwo kanoniczne, Warszawa 2011, s. 407.

7 cIC, c. 1501; por. M. Greszata, Kanoniczny proces zwyczajny w ujęciu Księdza Profesora Jerzego Grzywacza, Lublin 2007, s. 23. 
Sędzia kościelny to osoba, która pełni urząd publiczny, na mocy którego ma prawo osądzić sprawy i przywracać sprawiedliwość ${ }^{8}$. Urząd sędziego może pełnić osoba duchowna i świecka9. W znaczeniu kościelnym jest to osoba mająca udział w kościelnej władzy sądowej, dzięki czemu może rozpatrywać i rozstrzygać spory zgodnie z prawem kościelnym ${ }^{10}$. Należy do urzędów publicznych, gdyż służy dobru wspólnemu Kościoła katolickiego $^{11}$. Stoi na straży praworządności w życiu społecznym. Nie działa on na mocy własnego autorytetu, lecz na podstawie jurysdykcji sądowej, prawnie uzyskanej wraz z pełnią władzy rządzenia ${ }^{12}$. Sędziemu kościelnemu w każdym procesie przysługuje wolność w podejmowaniu decyzji, którą przyznaje mu prawodawca, jednocześnie wymagający od niego odpowiednich kwalifikacji i kompetencji oraz precyzyjnego zachowania procedury, prawidłowego administrowania sprawiedliwością oraz moralnej pewności przy wyrokowaniu. Sędzia kościelny jest zobowiązany przedstawioną mu wątpliwość rozstrzygnąć zgodnie z wynikami zebranego materiału dowodowego, normami prawnymi i swoim wewnętrznym przekonaniem ${ }^{13}$.

Sędzia jest osobą, której powierzono w procesie ważne zadania w zakresie stosowania ustaw do konkretnych wypadków. Jego zadanie polega na wymierzeniu sprawiedliwości, dlatego powinien dążyć do prawdy

8 R. Sztychmiler, Sądownictwo kościelne w służbie praw człowieka, Olsztyn 200o, s. 58; por. S. Pikus, Sędzia kościelny w świetle zadań i uprawnień procesowych, „Prawo Kanoniczne" 45 (2002) nr 3-4, s. 269-284.

9 CIC, c. 1421, $\$ 2$; por. DC, art. 43, \$2; R. Sztychmiler, Tytuł II. Trybunaty, [w:] Komentarz do Instrukcji procesowej „Dignitas connubii”, red. T. Rozkrut, Sandomierz 2007, s. 86; J. Laskowski, Udziat świeckich w aktywizowaniu duszpasterstwa (aspekt teologiczno-prawny), [w:] Duszpasterstwo w świetle nowego Kodeksu Prawa Kanonicznego, red. J. Syryjczyk, Warszawa 1985, s. 125.

${ }^{10}$ A. Dzięga, Władza sędziego kościelnego, [w:] Urzędy sądowe - władza i stużba. Materiały z ogólnopolskiego spotkania pracowników sądownictwa kościelnego w Gródku nad Dunajcem w dniach 11-12 października 2004 roku, red. T. Rozkrut, Tarnów 2005, s. 24.

${ }^{11}$ J. Weber, Der Diözesanrichter. Verfassungsrechtliche Gestalt und gegenwärtige Ausgestaltung, [w:] Kirchliches Recht als Freiheitsordnung, Gedenkschrift Hubert Müller, Würzburg 1997, s. 261-277.

${ }^{12}$ Por. R. Sobański, Tytuł viII. Władza rządzenia, [w:] Komentarz do Kodeksu Prawa Kanonicznego, T. 1. Ks. 1. Normy ogólne, red. J. Krukowski, Poznań 2007, s. 220-222.

${ }^{13}$ M. Greszata, Iudicium cum principiis. Kodeksowa weryfikacja wybranych zasad procesowych w kanonicznych sprawach o nieważność matżeństwa, Lublin 2008, s. 283-284. 
obiektywnej ${ }^{14}$. Należy zaznaczyć, że sędzia w trybunale, w prowadzonym procesie spełnia funkcje kierownicze i decyzyjne ${ }^{15}$. W znaczeniu ogólnym jest osobą piastującą urząd publiczny, na mocy którego może on sądzić sprawy przedłożone mu zgodnie z prawem i wyrokować ${ }^{16}$. Ma on udział w kościelnej władzy sądowniczej przez pełnienie urzędu sędziowskiego ${ }^{17}$. Urząd ten jest powierzony na sposób stały, by mógł rozpatrywać i autentycznie rozstrzygać sprawy zgodnie z prawem, własną wiedzą fachową, doświadczeniem i sumieniem ${ }^{18}$.

W Kodeksie prawa kanonicznego, jak i w Kodeksie kanonów Kościołów wschodnich nie znajdujemy definicji urzędu sędziego. Dlatego też pomocą w zdefiniowaniu urzędu sędziego jest literatura kanonistyczna. Na szczególną uwagę zasługuje definicja Andrzeja Dzięgi, który podaje, że: „sędzia kościelny jest to osoba duchowna, wyjątkowo osoba świecka, ale zawsze nienaruszonej sławy i fachowo przygotowana, powołana decyzją biskupa diecezjalnego do przyjmowania, wyjaśniania i rozstrzygania sporów między wiernymi w sposób zgodny z przepisami prawa procesowego"'19. Osoby te powinny być nienaruszonej sławy i mieć stopień doktora lub przynajmniej licencjata prawa kanonicznego ${ }^{20}$. W oparciu o taki obraz sędziego kościelnego, który uwzględnia szczegółowe dyspozycje kodeksowe, możemy usystematyzować główne zadania, jakie wiążą się z pełnieniem tego urzędu, polegającego na sprawiedliwym stosowaniu prawa w Kościele ${ }^{21}$.

Podstawowym zadaniem wszelkich urzędów w Kościele katolickim jest uwzględnienie potrzeb wiernych w aktach wykonywanych przez władzę

${ }^{14}$ Jan Paweł II, Przemówienie do Roty Rzymskiej, 04.02.1980r., „Acta Apostolicae Sedis” [dalej: AAs] 72 (1980), s. 176-177.

${ }_{15}$ Por. G. Erlebach, Tytuł I. Procesy..., dz. cyt., s. 32.

${ }_{16}$ Por. T. Pawluk, Prawo kanoniczne według kodeksu Jana Pawła II, t. 4, Olsztyn 199o, s. 182, R. Sztychmiler, Sądownictwo kościelne w służbie praw człowieka, dz. cyt., s. 58; M. Greszata, Iudicium..., dz. cyt., s. 283.

${ }^{17}$ CIC, c. $145, \S 1$; por. S. Pikus, Sędzia kościelny $w$ świetle zadań i uprawnień procesowych, „Prawo Kanoniczne” 45 (2002) nr 3-4, s. 269-270.

${ }^{18}$ S. Pikus, Sędzia kościelny..., dz. cyt., s. 270.

19 A. Dzięga, Strony sporu w kanonicznym procesie o nieważność małżeństwa, Warszawa 1994, s. 19.

${ }^{20}$ CIC, c. $1421, \$ \$ 1-3$; por. DC, art. 43, $\$ 3$; R. Sztychmiler, Tytuł II. Trybunały..., dz. cyt., s. 87.

${ }^{21}$ S. Pikus, Sędzia kościelny..., dz. cyt., s. 269-270. 
kościelną. Obecne prawo kanoniczne podaje, że urząd kościelny jest ustanowionym na stałe zadaniem, z postanowienia Bożego lub kościelnego, dla realizacji celów duchowych ${ }^{22}$. A zatem sędzia kościelny pełni swój urząd sądowniczy w celu realizacji dobra publicznego wspólnoty Kościoła, którym jest przywrócenie naruszonego porządku prawnego i jego ochrony, dlatego konieczne jest wyposażenie go w odpowiednie kompetencje prawne. Jeśli istotny zadaniem norm prawa procesowego jest ochrona praw podmiotowych, przysługującym stronom procesowym, to sytuacja sędziego $\mathrm{w}$ procesie stanowi ich odzwierciedlenie. Dlatego sędzia kościelny może działać jedynie w obszarze określonym przez prawodawcę kanonicznego ${ }^{23}$.

Przyjęcie skargi przez sędziego to nieodzowny element procesu o stwierdzenie nieważności małżeństwa. Sędzia nie może rozpocząć sprawy, jeśli ten, kto jest zainteresowany, nie przedstawi prośby zgodnie z przepisami prawa kanonicznego ${ }^{24}$. Prawodawca zabrania sędziemu postępowania bez skargi powodowej pod sankcją nieważności procesu ${ }^{25}$. Przyjmując skargę i prowadząc proces, sędzia nie może decydować o tym, czego nie ma w skardze powodowej, dlatego wspomniana skarga powodowa wyznacza przedmiot sporu, a następnie wyrokowania. W sprawach o stwierdzenie nieważności małżeństwa prośbę skierowaną do sędziego przedstawiają zazwyczaj małżonkowie ${ }^{26}$. Sprawy o stwierdzenie nieważności małżeństwa są zastrzeżone do rozstrzygania przez kolegium trzech sędziów ${ }^{27}$. Rozpoznania sprawy dokonują sędziowie po przyjęciu skargi powodowej i ustaleniu formuły sporu poprzez pozostałe czynności procesowe, jakimi są: procedura dowodzenia, procedura dyskusji sprawy i procedura zmierzająca do rozstrzygnięcia sprawy wyrokiem, w których realizuje się ich władza sędziowska. Temu celowi mają służyć wszelkie działania podejmowane przez sędziego, począwszy od zawiązania sporu, przez cały przewód sądowy, a także przez ewentualne rozpatrywanie

${ }^{22}$ Po, nr 20; por. S. Pikus, Sędzia kościelny..., dz. cyt., s. 275.

${ }_{23}$ S. Pikus, Sędzia kościelny..., dz. cyt., s. 276.

${ }^{24}$ CIC, c. 1501; por. DC 114; S. Pikus, Sędzia kościelny..., dz. cyt., s. 270.

${ }^{25}$ S. Pikus, Sędzia kościelny..., dz. cyt., s. 270.

${ }^{26}$ I. Gordon, Nowy proces nieważności małżeństwa, tłum. J. Walicki, Częstochowa 1983, s. 16; por. S. Pikus, Sędzia kościelny..., dz. cyt., s. 270.

${ }^{27}$ Por. R. Sztychmiler, Tytut II. Trybunały..., dz. cyt., s. 86. 
zaistniałych spraw wypadkowych ${ }^{28}$. Papież Franciszek, ogłaszając dwa dokumenty motu proprio Mitis iudex Dominus Iesus ${ }^{29}$ i Mitis et misericors $\operatorname{Iesus}^{30}$, wprowadza zmiany do procesu kanonicznego o stwierdzenie nieważności małżeństwa. Nowe przepisy mają na celu przyspieszenie i usprawnienie procedur dotyczących stwierdzenia nieważności. W szczególności zostaje zniesiona konieczność dwóch zgodnych orzeczeń i zostaje wprowadzony tzw. krótki proces processus brevior, a w centrum zostaje postawiona postać i rola biskupa diecezjalnego lub eparchy (w przypadku katolickich Kościołów wschodnich) jako sędziego w procesach.

Od sędziego kościelnego wymaga się pewności moralnej co do stwierdzenia nieważności małżeństwa. Jednocześnie prawodawca zaznacza, że do uzyskania wymaganej przez prawo kanoniczne pewności moralnej nie wystarczy przeważająca moc dowodowa i poszlaki, lecz wymaga się, by wykluczona była nawet jakakolwiek rozumna wątpliwość pozytywna, tak co do stanu prawnego, jak i faktycznego, choć nie da się wykluczyć zwykłej możliwości czegoś przeciwnego ${ }^{31}$. Wprowadzenie pojęcia pewności moralnej spowodowało postęp w kanonicznym prawie procesowym, w doskonaleniu wymiaru sprawiedliwości w Kościele katolickim. Pojęcie to daje sędziemu kościelnemu jasne kryteria, w jakim stanie umysłu winien sędzia wydać wyrok w rozpatrywanej sprawie. Zenon Grocholewski stwierdza, że jest to kryterium realistyczne, biorące pod uwagę granice ludzkiego umysłu i równocześnie całkowity szacunek dla prawdy. Jednocześnie jest to kryterium odzwierciedlające roztropność i racjonalnośćs ${ }^{32}$. Pewność moralną sędzia może osiągnąć, gdy oprócz uzyskanych środków dowodowych obligatoryjnie zachowa przepisy kościelnego prawa pro-

${ }^{28}$ S. Pikus, Sędzia kościelny..., dz. cyt., s. 271.

${ }^{29}$ Litterae Apostolicae Motu Proprio datae Mitis et misericors Iesus quibus canones Codicis Canonum Ecclesiarum Orientalium de causis ad matrimonii nullitatem declarandam reformantur (die Xv mensis Augusti, anno MMxv) vatican.va/content/francesco/la/motu_ proprio/documents/papa-francesco-motu-proprio_20150815_mitis-iudex-dominus-iesus. html (11.01.2016).

${ }^{30}$ Litterae Apostolicae Motu Proprio datae Mitis Iudex Dominus Iesus quibus canones Codicis Iuris Canonici de causis ad matrimonii nullitatem declarandam reformantur (die XV mensis Augusti, anno MMXv), vatican.va/content/francesco/la/motu_proprio/documents/papa-francesco-motu-proprio_20150815_mitis-et-misericors-iesus.html (11.01.2016).

${ }^{31}$ DC, art. 247, \$ 2; por. W. Góralski, Matżeństwo kanoniczne, dz. cyt., s. 436.

${ }^{32}$ Z. Grocholewski, Pewność moralna jako klucz do lektury norm prawnych, „Ius Matrimoniale" 3 (9) 1998, s. 41. 
cesowego oraz wykaże solidne przygotowanie do urzędu sędziowskiego. Oprócz tego powinien cechować się właściwymi, indywidualnymi predyspozycjami osobowościowymi. Wszystkie powyższe czynniki dają gwarancję solidnej, sumiennej oceny zgromadzonych dowodów, która może doprowadzić do pewności moralnej. Według św. Jana Pawła II żaden sędzia nie może wydać wyroku uznającego, że małżeństwo było nieważnie zawarte, jeśli wcześniej w swoim sumieniu nie uzyskał stanu pewności moralnej. Podkreślił także, że do rozstrzygnięcia sprawy sądowej o stwierdzenie nieważności małżeństwa nie wystarczy tylko prawdopodobieństwo ${ }^{33}$. Pewność moralną sędzia powinien czerpać $\mathrm{z}$ akt i dowodów zgromadzonych w toczącej się sprawie o stwierdzenie nieważności małżeństwa ${ }^{34}$. Natomiast osąd dowodów sędzia winien ocenić według własnego sumienia, jednakże zawsze $\mathrm{z}$ zachowaniem przepisów prawa kanonicznego o skuteczności dowodów ${ }^{35}$.

Przekonanie sędziowskie nie może sprowadzać się tylko do subiektywnego poczucia pewności, jak również nie można go rozpatrywać wyłącznie w aspekcie psychologicznym jako stanu świadomości sędziego. Sędzia przystępujący do rozpatrywania przedłożonej mu sprawy nie może mieć już wewnętrznego przekonania sędziowskiego, ponieważ ono powstaje dopiero w wyniku rozpatrywania sprawy, i to po sprawdzeniu wszystkich zebranych środków dowodowych oraz po uwzględnieniu całości okoliczności sprawy sądowej. Gdyby sędzia przed rozpatrywaniem sprawy miał już przekonanie o niesłuszności bądź słuszności faktów przedstawionych w sądzie przez strony, nie byłoby to przekonanie sędziowskie, lecz uprzedzenie, które wyklucza obiektywne rozpatrzenie sprawy, a tym samym dojście do obiektywnej prawdy ${ }^{36}$.

Orzeczenie sędziego kościelnego to wynik pewnego procesu myślowego, polegającego na przyporządkowaniu stanu faktycznego oraz przepisów prawa kanonicznego. Sobański stwierdza, że stan faktyczny trzeba

${ }^{33}$ Jan Paweł II, Przemówienie do Roty Rzymskiej, 04.02.1980r., AAs 72 (1980) nr 6, s. 176.

${ }^{34}$ DC, art. $247, \$ 3$; por. A. Stankiewicz, La certezza morale e la motivazione dell sentenza, [w:] La nullità del matrimonio: temi processuali e sostantivi in occasione della „Dignitas connubii”, a cura di H. Franceschi, J. Liobell, M. A. Ortiz, Roma 2005, s. 231-245.

${ }_{35}$ DC, art. $247, \S 4$; por. CIC, c. $1608, \S 3$; W. Góralski, Małżeństwo kanoniczne, dz. cyt., S. 436.

${ }^{36}$ T. Pawluk, Ocena sędziowska środków dowodowych w procesie kanonicznym, „Prawo Kanoniczne" 12 (1969), nr 1-2, s. 153-154. 
poznać, natomiast przepisy prawa kanonicznego - rozumieć. Prawo daje wskazania odnośnie do rozumienia norm, ale przy stosowaniu prawa nie wystarczy ich rozumieć ogólnie i doktrynalnie, lecz trzeba wydobyć ich znaczenie w konkretnym, rozpatrywanym przypadku. Jednak podstawowa trudność, jakiej sędzia musi stawić czoło, nie tkwi w tym, że przypada mu orzekać o akcie wewnętrznym, lecz w tym, że sędzia stosuje normy, które są wynikiem przyporządkowania dwóch dóbr podlegających ochronie, a pozostających w napięciu tożsamości małżeństwa oraz prawa osoby ludzkiej do zawarcia małżeństwa. Żadnej z tych wartości nie wolno przeakcentować kosztem drugiej - ani na etapie stanowienia prawa, ani w procesie jego stosowania ${ }^{37}$.

\section{Uprawnienia sędziego kościelnego}

Sędzia kościelny uczestniczy w sprawowanym przez Kościół katolicki wymiarze sprawiedliwości. Uprawnienia przysługujące sędziemu mają charakter personalny. Ze swej natury przysługują one jednej osobie. Są związane z podmiotem pełniącym urząd sędziego, co oznacza, że zostały mu nadane w sposób trwały. Zespół uprawnień i obowiązków ma dopomóc sędziemu w realizacji zadań przekazanych $\mathrm{z}$ chwilą prawnego objęcia urzędu ${ }^{38}$. Uprawnienia sędziego powinny być rozumiane jako poszanowanie obiektywnych i nienaruszalnych praw człowieka ${ }^{39}$. Szczególnym elementem władzy sędziego, mającym wpływ na prawo podmiotowe jemu przysługujące, a stanowiącym gwarancję wszystkich uprawnień, jest jego niezawisłość.

Sędzia, rozstrzygający sprawę występuje w procesie na mocy władzy zwyczajnej i podobnie jak biskup diecezjalny działa w imieniu Jezusa Chrystusa. Dlatego każda decyzja sędziego kościelnego staje się ostatecznie decyzją całkowicie niezawisłą, wolną i podejmowaną w sumieniu ${ }^{40}$. Zasada niezawisłości sędziowskiej stanowi dyrektywę dla sędziego, aby

${ }^{37}$ R. Sobański, Uwagi o tożsamości sędziego kościelnego, „Prawo Kanoniczne” 45 (2002) nr 3-4, s. 10-11.

${ }^{38}$ S. Pikus, Sędzia kościelny..., dz. cyt., s. 275-276.

${ }^{39}$ Jan Paweł II, enc. Redemptor hominis, 14; por. S. Pikus, Sędzia kościelny..., dz. cyt., s. 276.

${ }^{40}$ A. Dzięga, Strony procesowe..., dz. cyt., s. 18-19; por. S. Pikus, Sędzia kościelny..., dz. cyt., s. 277. 
orzekał zawsze na podstawie i w granicach ustaw oraz w zgodzie ze swoim przekonaniem, popartym pewnością moralną. Oznacza to, że oprócz prawodawcy nikt nie może wpływać na sędziego w realizowanym przez niego wymiarze sprawiedliwości ${ }^{41}$.

Następstwem zasady niezawisłości sędziego jest zadanie samodzielnego rozstrzygania przez niego kwestii dotyczących wykładni obowiązujących przepisów oraz nieskrępowana ocena wartości i wiarygodności przeprowadzonych dowodów. Sędzia powinien być wolny od wpływów innych osób w całym przebiegu procesu ${ }^{42}$. Sędzia kościelny, względnie przewodniczący kolegium trybunału, może drogą delegacji zlecić pewne funkcje $\mathrm{z}$ zakresu zadań sędziowskich innemu sędziemu nieorzekającemu w danej sprawie, a nawet osobie spoza trybunału, tym niemniej osoba ta postępuje wówczas zazwyczaj ściśle według instrukcji, przygotowanej przez sędziego zlecającego ${ }^{43}$. Wynika $\mathrm{z}$ tego, że istotne jest, w jaki sposób osoba mająca uprawnienia sędziego pojawia się $\mathrm{w}$ procesie.

\section{Sędzia kościelny mediatorem w sprawach małżeńskich}

Kościół katolicki jest zainteresowany stabilnością i trwałością małżeństw, stąd wynika nadrzędny obowiązek użycia środków duszpasterskich zmierzających do wznowienia wspólnoty życia małżeńskiego i ewentualnego uzdrowienia nieważności ${ }^{44}$. Należy zwrócić uwagę na zadanie sędziego kościelnego, szczególnie aktualne w obecnych czasach, jakim jest mediacja pomiędzy małżonkami. Małżeństwo i rodzina otoczone są przez Kościół szczególną troską pasterską, która powinna być obecna w posłudze każdego sędziego, który na mocy powierzonego mu urzędu zajmuje się sprawą o stwierdzenie nieważności małżeńskiej ${ }^{45}$.

${ }^{41}$ S. Pikus, Sędzia kościelny..., dz. cyt., s. 277.

${ }^{42}$ Por. K. Marszał, Proces karny, Katowice 1997, s. 49-50; S. Pikus, Sędzia kościelny..., dz. cyt., s. 277 ,

${ }_{43}$ CIC, c. 1428, \$ 1 i 3; por. S. Pikus, Sędzia kościelny..., dz. cyt., s. 277-278.

${ }^{44}$ Por. G. Erlebach, Tytuł I. Procesy..., dz. cyt., s. 340.

${ }^{45}$ W. Kiwior, Tytuł II. Zasady działania Sądów, [w:] Komentarz do Instrukcji procesowej „Dignitas connubii”, red. T. Rozkrut, Sandomierz 2007, s. 124. 
Prawodawca postanawia, że przewodniczący wyznaczonego przez wikariusza sądowego trybunału lub sędzia trybunału jednoosobowego ${ }^{46}$ przed podjęciem decyzji i wydaniem stosownego dekretu o przyjęciu lub odrzuceniu wniesionej przez stronę powodową skargi powodowej ma obowiązek zastosować środki pasterskie w celu ratowania zawartego małżeństwa ${ }^{47}$. We współczesnej procedurze sądowej powinno się położyć wielki nacisk na podejmowanie mediacji pomiędzy małżonkami, którzy chcą wnieść sprawę do sądu. Obowiązek ten spoczywa na osobie pełniącej urząd sędziego i jest właściwy pasterskiemu charakterowi jego urzędu $^{48}$. Prawodawca w kanonie 1676 wskazuje, by w miarę możliwości unikać wytaczania sporów. Prawodawca nakazuje sędziemu stosować środki pasterskie, jakie uzna za stosowne w celu doprowadzenia małżonków do pojednania ${ }^{49}$. Z tym łączy się posiadanie odpowiednich kwalifikacji przez sędziego $\mathrm{w}$ tej materii, by mógł, jeśli to możliwe, zaradzić ich problemom i zachęcić ich do podjęcia dalszego życia we wspólnocie małżeńskiej.

Po otrzymaniu skargi powodowej sędzia powinien przede wszystkim ocenić, czy istnieje możliwość pogodzenia małżonków i ewentualnego uważnienia ich zgody małżeńskiej, jeśli jest taka konieczność. Samo uzdrowienie byłoby nieużyteczne bez pogodzenia się i ponownego zawiązania wspólnoty życia. Sędzia może poczynić stosowne wysiłki osobiście lub poprzez inną osobę (np. proboszcz, pracownik poradni prawnej przy sądzie czy inny doświadczony duszpasterz). A zadaniem sędziego będzie ocena, $w$ jakiej mierze dana sytuacja rokuje nadzieję pogodzenia się małżonków ${ }^{50}$. W każdym razie obie strony muszą odznaczać się zdolnością do małżeństwa i być wolne od przeszkód zrywających, od których nie można dyspensowaćs1. Bardzo mocno o mediacji przypomniał

${ }^{46}$ DC, art. 30, \$ 3; por. R. Sztychmiler, Tytuł II. Trybunały..., dz. cyt., s. 69-70.

${ }^{47}$ DC, 65, \$ 1; por. W. Kiwior, Tytuł II. Zasady działania Sadów, [w:] Komentarz do Instrukcji procesowej „Dignitas connubii”, dz. cyt., s. 124.

${ }^{48}$ Jan Paweł II, Przemówienie do Roty Rzymskiej, 18.o1.199or., AAS 82 (1990), s. 874-877; por. G. Erlebach, Tytuł I. Procesy..., dz. cyt., s. 340.

49 Cic, c. 1676; por. L. Madero, Część III. Niektóre procesy specjalne, [w:] Kodeks Prawa Kanonicznego. Komentarz. Powszechne i partykularne ustawodawstwo Kościoła katolickiego. Podstawowe akty polskiego prawa wyznaniowego, red. P. Majer, Kraków 2011, s. 1255.

${ }^{50}$ W. Kiwior, Tytut II. Zasady..., dz. cyt., s. 124.

${ }^{51}$ Por. G. Erlebach, Tytuł I. Procesy..., dz. cyt., s. 340. 
św. Jan Paweł II, który to w przemówieniu do Trybunału Roty Rzymskiej mówił o konieczności bardzo poważnego traktowania obowiązku podjęcia starań o uważnienie małżeństwa i pojednanie małżonków, nałożonego na sędziego przez prawo kanoniczne. Obowiązek, jaki spoczywa na sędzim, wynika z pełnionego przez niego urzędu kościelnego ${ }^{52}$.

Środki pastoralne powinny być podejmowane przez sędziego, ilekroć dostrzeże on nadzieję doprowadzenia do pogodzenia się małżonków i rozpoczęcia przez nich ponownie życia wspólnego, a więc niezależnie od tego, na jakim etapie znajduje się sprawa, nawet przy okazji ogłoszenia wyroku niestwierdzającego nieważność małżeństwa ${ }^{53}$. Jeśli nie byłoby możliwe pogodzenie stron i konieczne byłoby rozpoczęcie procesu o stwierdzenie nieważności małżeństwa, sędzia powinien - w zależności od potrzeby - zachęcić albo i wezwać strony do szczerej współpracy $\mathrm{w}$ procesie, $\mathrm{w}$ duchu prawdy i miłości, tak by została stwierdzona prawda obiektywna co do ważności lub nieważności ich małżeństwa ${ }^{54}$.

\section{Zakończenie}

Reasumując powyższe rozważania, należy zaznaczyć, że zostały podkreślone zadania i uprawnienia sędziego kościelnego, powołanego do realizowania we wspólnocie ludu Bożego wymiaru sprawiedliwości. Sędzia kościelny, pełniąc urząd, uczestniczy w sprawowaniu pasterskiej troski o Kościół katolicki. W procedurze sądowej powinno kłaść się duży nacisk na podejmowanie mediacji pomiędzy małżonkami, którzy chcą wnieść do sądu kościelnego sprawę o stwierdzenie nieważności ich małżeństwa. $\mathrm{Z}$ tym łączy się odpowiednie przygotowanie i dyspozycje sędziego w tej materii, by mógł, jeśli jest to możliwe, zaradzić ich problemom i skłonić ich do dialogu i podjęcia dalszego życia we wspólnocie małżeńskiej. Zakres obowiązków i praw przysługujących sędziemu ma mu dopomóc w sprawnym przeprowadzeniu procesu, możliwie najbardziej wnikliwym rozpoznaniu sporu oraz wewnętrznie pewnym moralnie rozstrzygnięciu

${ }^{52}$ Jan Paweł II, Przemówienie do Roty Rzymskiej, 30.01.2003r., AAS 95 (2003), s. 396-397, nr 7 .

53 Por. G. Erlebach, Tytuł I. Procesy..., dz. cyt., s. 341.

${ }^{54}$ DC, art. 65, $\$ \$ 2-3$; por. G. Erlebach, Tytut I. Procesy..., dz. cyt., s. 341; L. Madero, Część III. Niektóre..., dz. cyt., s. 1255. 
oraz wyrokowaniu. Sędzia w sądownictwie kościelnym jest gwarantem prawdy obiektywnej, ponieważ jego decyzje są decyzjami podejmowanymi w imię Boga. Zadania i uprawnienia sędziego kościelnego mają na celu dobro wspólne oraz umocnienie sprawiedliwości jako podstawy stosunków międzyludzkich. Sędzia sprawujący w Kościele wymiar sprawiedliwości musi korzystać z przyznanych uprawnień, pamiętając też o przestrzeganiu przepisów wyznaczonych mu przez prawodawcę. Powinien czynić to, na co pozwala prawo kanoniczne. 